\title{
Effect of Etiolation, Wrapping Materials and Media on Rooting and Survival in Air Layering of Guava (Psidium guajava L.) cv. Allahabad Safeda
}

\author{
H.J. Chaudhari", B.H. Panchal, N.G. Patel and N.K. Sutariya \\ Department of Horticulture, B. A. College of Agriculture, Anand Agricultural University, \\ Anand-388 110, Gujarat, India \\ *Corresponding author
}

\section{Keywords}

Etiolation, Wrapping materials, Media,

Guava, Sphagnum moss, Air layers

Article Info

Accepted:

04 July 2018

Available Online:

10 August 2018

A B S T R A C T

An investigation entitled "Effect of etiolation, wrapping materials and media on rooting and survival in air layering of guava (Psidium guajava L.) cv. Allahabad Safeda" was conducted at Horticultural Research Farm, B. A. College of Agriculture, Anand Agricultural University, Anand during the year Kharif - 2017, to find out suitable combination of treatments for rooting and survival of air layers without using rooting hormones in guava. The result revealed that survival of rooted layers and root characters of air layers of guava have been successfully achieved by the etiolation. Regarding the wrapping materials, in black polythene (200 guage) gave the high survival rooted air layers and root characters at detachment (45 days), 30 and 60 days after shifting in poly bags. Among the rooting media, moist sphagnum moss found to be best and produced highest survival and root characters. The survival of rooted air layers root characters viz., number of primary and secondary roots, fresh and dry weight of roots at detachment (45 days from mother plants) was found to be maximum with the treatment combination of etiolation and sphagnum moss.

\section{Introduction}

Guava (Psidium guajava L.) is a native of Tropical America (from Mexico to Peru) and belongs to family Myrtaceae. Guava is the fourth important fruit crop after mango, banana and citrus. It is hardy in nature. It gives an assured crop even with very little care. It is cultivated in India since early 17 th century. Guava is one of the most common fruits liked by the rich and the poor community and is popularly known as the "Apple of the tropics". Its cost of production is also low because its fertilizer, irrigation and plant protection requirements are very less. Further, its nutritive value is very high. Fruit is rich in vitamin $\mathrm{C}$ content and also a good source of vitamin-A and B, iron, calcium and phosphorus. Allahabad Safeda is the most famous variety of India. It has acquired wide variations due to seed propagation. The fruits are large in size, round in shape, skin smooth and yellowish-white. The flesh is white, firm, soft having pleasant flavour, high TSS and vitamin $\mathrm{C}$ contents. The seeds are numerous, bold and hard. The trees are tall with profuse 
branching having broad crown and it can withstand in drought condition (Chadha 2006). Etiolation in plants occurs when they are grown in either partial or a complete absence of light. Etiolation may reduce the production of lignin, thus instead of forming lignin phenolic metabolic may be channeled to enhance root initiation. Polythene wrappers have properties which in some respects makes it similar to the outer skin of plants. It is water proof, transmits light and allows gaseous exchange of oxygen and carbon-dioxide and low transmission of water vapour. Two colours of polythene wrappers i.e. black and white will be used at the time of operation. Sphagnum moss has higher moisture holding capacity with lighter weight, which enhances root formation.

\section{Materials and Methods}

Present investigation was conducted at Horticulture Research Farm, Anand Agricultural University, Anand, from June to November during the year 2017. The experiment was laid out in a Completely Randomized Design (Factorial) with twenty (20) treatment combinations and replicated thrice. Twelve years old healthy, well matured, uniform and vigorous 60 guava trees planted at $6 \times 6 \mathrm{~m}$ in square system were selected for the study from the guava orchard. After selection of plants, shoots of uniform age (one year old), size (50 to $60 \mathrm{~cm}$ length) and pencil thickness were randomly selected for air layering. The experimental unit consisted of 30 shoots in each treatment. Etiolation process before 30 day $\left(1^{\text {st }}\right.$ June $)$ of air layering black polythene wrapping was done and then followed ringing ( $1^{\text {st }}$ August). Etiolation was carried out during the month of June. Two colours of polythene wrappers i.e. black and white (200 gauges) were used at the time of operation. Various rooting media viz., soil and sphagnum moss was used for rooting in air layering. Initially sphagnum moss was soaked in water for about one hour before use and then a small quantity of moss was applied to cover the ring of the shoot. The leaves were removed from the base of the selected shoot and then it was ringed by removing bark of about 2.5 to $3 \mathrm{~cm}$ carefully by giving two circular cuts with a sharp knife at about 45 to $60 \mathrm{~cm}$ below the top end of the shoots and then the exposed portion was rubbed. All the open rings were wrapped with media followed by polythene wrapper and kept for rooting. Air layering was carried out during the month of July.

The rooted air layers were separated from the parent plants after emergence of roots in three stages to reduce the shock of sudden separation at 45 days after air layering. Air layering separation was carried out during the month of September. Black polythene bags of $6 " \times 8$ " size were filled with soil. One air layer of the guava was dibbled at about 2 to $3 \mathrm{~cm}$ depth in each polythene bag. For each replication 600 polythene bags were filled and kept in $75 \%$ green shed net house. The treatments comprised of two levels of etiolation i.e. $\left(\mathrm{E}_{0}\right)$ without etiolation (under light condition) and $\left(\mathrm{E}_{1}\right)$ with etiolation (under dark condition) as well as two levels of wrapping materials $\left(\mathrm{W}_{1}\right)$ Black poly wrapper (200 gauge) and $\left(\mathrm{W}_{2}\right)$ Transparent poly wrapper (200 gauge) with five level of growing media (M) viz., $\mathrm{M}_{1^{-}}$Soil, $\mathrm{M}_{2^{-}}$ Sphagnum moss, $\mathrm{M}_{3^{-}}$Sphagnum moss + Soil (1:2), $\mathbf{M}_{4}$ - Sphagnum moss + Soil (1:1), $\mathbf{M}_{5^{-}}$ Sphagnum moss + Soil (2:1). Five air-layers were selected from each treatment i.e. fifteen from all three replications for observation at the time of detachment of air-layers. Observations were recorded in respect to number of primary root, number of secondary root, fresh weight of root, dry weight of root at the time of detachment. While, at detachment, 30 and 60 days after planting survival percent of rooted layers and total fresh weight of layers, total dry weight of layers. 
The recorded data were analyzed statistically using various techniques as described by Panse and Sukhatme (1978). The treatment means were compared with C.D. at 5 per cent level.

\section{Results and Discussion}

\section{Effect of etiolation}

The perusal of data showed the significant effect of etiolation on rooting attributes and survival percentage (Table 1 and 2). Layering after 45 day at the time of detachment etiolation $\left(E_{1}\right)$ recorded maximum number of primary roots (7.73), secondary roots (24.03), fresh and dry weight of root i.e. $2.049 \mathrm{~g}, 0.434$ $\mathrm{g}$, respectively at 45 day of air layering as well as incredible trade in total fresh and dry weight of layers at detachment, 30 and 60 days.

While, at detachment, $30^{\text {th }}$ and $60^{\text {th }}$ days after planting $\left(\mathrm{E}_{1}\right)$ observed maximum survival percent of rooted layers $(64.98 \%, 59.80 \%$ and $56.36 \%$, respectively), total fresh weight of layers $(17.85 \mathrm{~g}, 23.10 \mathrm{~g}$ and $31.42 \mathrm{~g}$, respectively), total dry weight of layers (8.37 $\mathrm{g}, 11.13 \mathrm{~g}$ and $14.97 \mathrm{~g}$, respectively). While, at $30^{\text {th }}$ and $60^{\text {th }}$ days after planting $\left(\mathrm{E}_{1}\right)$ observed maximum Incremental length of shoots (4.89 $\mathrm{cm}, 5.87 \mathrm{~cm})$, Incremental number of leaves (9.80, 6.26), Incremental number of branches $(3.14,2.30)$. It is a well-known fact that etiolated region contains high levels of endogenous root promoting substances, which facilitate rooting in both easy and hard-to-root plant species, as reported by Kunal and Shyamal (2005). Carbohydrate and other substances like natural auxins and rooting cofactors also get accumulated in the etiolated region, which helped in promoting all the factors conducive to facilitate easy and better rooting (Sengupta and Thakur, 2001). While maximum survival percent of rooted layers was recorded in $\mathrm{E}_{1}$.

\section{Effect of wrapping materials}

The data presented in (Table 1 and 2) revealed that layering after 45 day at the time of detachment, wrapping material $\left(\mathrm{W}_{1}\right)$ recorded maximum number of primary roots (7.30), numbers of secondary roots (23.16), fresh weight of root $(2.011 \mathrm{~g})$ and dry weight of root (0.437 g). However, at detachment, 30 and 60 days after planting $\left(\mathrm{W}_{1}\right)$ observed maximum survival percent of rooted layers $(64.30 \%$, $58.50 \%$ and $55.06 \%$, respectively), total fresh weight of layers $(17.57 \mathrm{~g}, 22.77 \mathrm{~g}$ and $30.34 \mathrm{~g}$, respectively) and total dry weight of layers (8.22 g, $10.97 \mathrm{~g}$ and $14.51 \mathrm{~g}$, respectively).

While, at $30^{\text {th }}$ and $60^{\text {th }}$ days after planting $\left(\mathrm{E}_{1}\right)$ observed maximum Incremental length of shoots $(4.77 \mathrm{~cm}, 5.74 \mathrm{~cm})$, Incremental number of leaves $(9.50,6.41)$, Incremental number of branches $(3.17,2.61)$. The highest effect of black poly wrapper on rooted layers might be due to the increased physiological activities essential for cell division or cell enlargement or both. The results are in concurrence with the findings of Singh and Bhuj (2000), Kanpure et al., (2015) and Singh et al., (1995) in guava, Sen and Chakraborty (1972) in cashew nut Mishra et al., (2017) in litchi.

\section{Effect of rooting media}

Among the different media, sphagnum moss had significantly affected on $g$ attribute and survival percent (Table 1 and 2). The maximum number of primary roots (12.08), secondary roots (37.58), fresh weight of root $(2.786 \mathrm{~g})$ and dry weight of root $(0.650 \mathrm{~g})$. Whereas, maximum survival percent of rooted layers $(75.25 \%, 74.00 \%$ and $71.66 \%$, respectively), total fresh weight of layers (23.66 g, $29.48 \mathrm{~g}$ and $41.91 \mathrm{~g}$, respectively), total dry weight of layers (11.15 g, $14.29 \mathrm{~g}$ and $19.88 \mathrm{~g}$, respectively) was recorded in treatment at detachment, 30 and 60 days after planting. 
Table.1 Effect of etiolation, wrapping materials and media on rooting and survival in air layering of guava (Psidium guajava L.) cv. Allahabad Safeda

\begin{tabular}{|c|c|c|c|c|c|c|c|c|c|c|c|c|c|}
\hline \multirow[t]{2}{*}{ Treatments } & \multirow{2}{*}{ 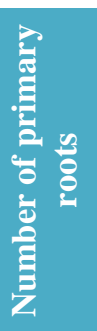 } & \multirow{2}{*}{ 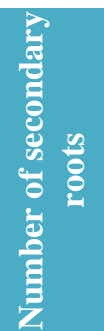 } & \multirow{2}{*}{ 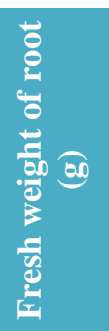 } & \multirow{2}{*}{ 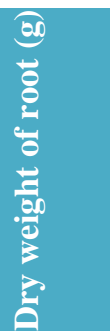 } & \multicolumn{3}{|c|}{$\begin{array}{c}\text { Survival percentage of } \\
\text { layers }\end{array}$} & \multicolumn{3}{|c|}{$\begin{array}{c}\text { Fresh weight of rooted } \\
\text { layers }(\mathrm{g})\end{array}$} & \multicolumn{3}{|c|}{ Dry weight of rooted layers (g) } \\
\hline & & & & & 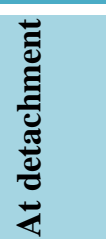 & 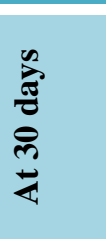 & 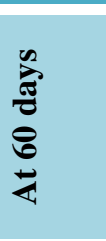 & 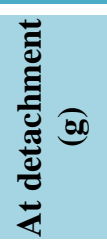 & 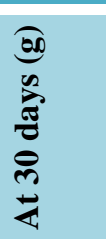 & 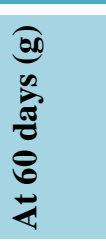 & 馬 & 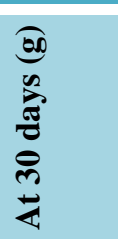 & 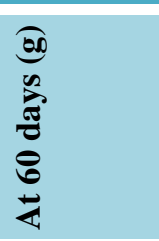 \\
\hline \multicolumn{14}{|l|}{ Etiolation (E) } \\
\hline $\mathbf{E}_{0}$ & 6.43 & 20.33 & 1.844 & 0.398 & 61.80 & 54.80 & 51.80 & 16.26 & 21.18 & 28.23 & 7.61 & 10.35 & 13.50 \\
\hline $\mathbf{E}_{1}$ & 7.73 & 24.03 & 2.049 & 0.434 & 64.98 & 59.80 & 56.36 & 17.85 & 23.10 & 31.42 & 8.37 & 11.13 & 14.97 \\
\hline S.Em. \pm & 0.12 & 0.24 & 0.016 & 0.006 & 0.19 & 0.25 & 0.31 & 0.09 & 0.12 & 0.15 & 0.04 & 0.07 & 0.12 \\
\hline C.D. at 5\% & 0.36 & 0.69 & 0.048 & 0.016 & 0.56 & 0.72 & 0.91 & 0.27 & 0.36 & 0.44 & 0.14 & 0.20 & 0.35 \\
\hline \multicolumn{14}{|c|}{ Wrapping materials (W) } \\
\hline $\mathbf{W}_{1}$ & 7.30 & 23.16 & 2.011 & 0.437 & 64.30 & 58.50 & 55.06 & 17.57 & 22.77 & 30.34 & 8.22 & 10.97 & 14.51 \\
\hline $\mathrm{W}_{2}$ & 6.86 & 21.20 & 1.882 & 0.395 & 62.47 & 56.10 & 53.10 & 16.54 & 21.51 & 29.32 & 7.77 & 10.51 & 13.96 \\
\hline S.Em. \pm & 0.12 & 0.24 & 0.016 & 0.006 & 0.19 & 0.25 & 0.31 & 0.09 & 0.12 & 0.15 & 0.04 & 0.07 & 0.12 \\
\hline C.D. at $\mathbf{5 \%}$ & 0.36 & 0.69 & 0.048 & 0.016 & 0.56 & 0.72 & 0.91 & 0.27 & 0.36 & 0.44 & 0.14 & 0.20 & 0.35 \\
\hline \multicolumn{14}{|l|}{ Rooting media (M) } \\
\hline $\mathrm{M}_{1}$ & 3.08 & 9.75 & 1.098 & 0.215 & 50.59 & 38.50 & 33.58 & 11.51 & 14.79 & 17.47 & 5.47 & 7.66 & 8.80 \\
\hline $\mathrm{M}_{2}$ & 12.08 & 37.58 & 2.786 & 0.650 & 75.25 & 74.00 & 71.66 & 23.66 & 29.48 & 41.91 & 11.15 & 14.29 & 19.88 \\
\hline$\overline{M_{3}}$ & 4.75 & 14.50 & 1.491 & 0.309 & 57.43 & 49.25 & 45.58 & 13.85 & 18.15 & 23.68 & 6.56 & 8.98 & 11.61 \\
\hline $\mathrm{M}_{4}$ & 6.66 & 21.16 & 2.028 & 0.425 & 64.31 & 58.41 & 55.00 & 16.31 & 22.13 & 30.65 & 7.49 & 10.12 & 14.07 \\
\hline $\mathrm{M}_{5}$ & 8.83 & 27.91 & 2.330 & 0.482 & 69.35 & 66.33 & 64.58 & 19.59 & 26.15 & 35.44 & 9.29 & 12.66 & 16.81 \\
\hline S.Em. \pm & 0.20 & 0.38 & 0.027 & 0.009 & 0.31 & 0.40 & 0.50 & 0.15 & 0.20 & 0.24 & 0.07 & 0.11 & 0.19 \\
\hline C.D. at 5\% & 0.57 & 1.09 & 0.076 & 0.025 & 0.89 & 1.14 & 1.44 & 0.43 & 0.57 & 0.71 & 0.22 & 0.32 & 0.55 \\
\hline C.V\% & 9.81 & 5.99 & 4.735 & 7.367 & 1.72 & 2.42 & 3.23 & 3.10 & 3.16 & 2.89 & 3.38 & 3.67 & 4.71 \\
\hline$(\mathrm{E} \times \mathrm{M})$ & Sig. & Sig. & Sig. & Sig. & Sig. & NS & NS & NS & Sig. & NS & Sig. & NS & NS \\
\hline$(\mathbf{W} \times \mathbf{M})$ & NS & NS & NS & NS & NS & NS & NS & NS & NS & NS & NS & NS & NS \\
\hline$(\mathrm{E} \times \mathbf{W})$ & NS & NS & NS & NS & NS & NS & NS & NS & NS & NS & NS & NS & NS \\
\hline$(\mathbf{E} \times \mathbf{W} \times \mathbf{M})$ & NS & NS & NS & Sig. & NS & NS & NS & NS & NS & NS & NS & NS & NS \\
\hline
\end{tabular}

Note:- $\mathrm{E}_{0}$ :- Without Etiolation, $\mathrm{E}_{1}$ :- With Etiolation, $\mathrm{W}_{1}$ :- Black poly wrapper (200 gauge), $\mathrm{W}_{2}$ :- Transparent poly wrapper (200 gauge), $\mathrm{M}_{1}$ :- Soil, $\mathrm{M}_{2}$ :Sphagnum moss, $\mathbf{M}_{3}$ :- Sphagnum moss + Soil (1:2), $\mathbf{M}_{4}:-$ Sphagnum moss + Soil $(1: 1), \mathrm{M}_{5}:-$ Sphagnum moss + Soil $(2: 1)$ 
Table.2 Effect of etiolation, wrapping materials and media on rooting and survival in air layering of guava (Psidium guajava L.) cv. Allahabad Safeda

\begin{tabular}{|c|c|c|c|c|c|c|c|c|c|}
\hline \multirow[t]{2}{*}{ Treatments } & \multirow{2}{*}{$\begin{array}{l}\text { Length of } \\
\text { shoots at } \\
\text { detachment }\end{array}$} & \multicolumn{2}{|c|}{$\begin{array}{l}\text { Incremental length of } \\
\operatorname{shoots}(\mathrm{cm})\end{array}$} & \multirow{2}{*}{$\begin{array}{c}\text { Number of } \\
\text { leaves at } \\
\text { detachment }\end{array}$} & \multicolumn{2}{|c|}{$\begin{array}{c}\text { Incremental number of } \\
\text { leaves }\end{array}$} & \multirow{2}{*}{$\begin{array}{l}\text { Number of } \\
\text { branches at } \\
\text { detachment }\end{array}$} & \multicolumn{2}{|c|}{$\begin{array}{c}\text { Incremental number of } \\
\text { branches }\end{array}$} \\
\hline & & $\begin{array}{l}\text { At } 0 \text { to } 30 \\
\text { days }(\mathrm{cm})\end{array}$ & $\begin{array}{l}\text { At } 30 \text { to } 60 \\
\text { days }(\mathrm{cm})\end{array}$ & & $\begin{array}{l}\text { At } 0 \text { to } 30 \\
\text { days }\end{array}$ & $\begin{array}{l}\text { At } 30 \text { to } 60 \\
\text { days }\end{array}$ & & $\begin{array}{l}\text { At } 0 \text { to } 30 \\
\text { days }\end{array}$ & $\begin{array}{c}\text { At } 30 \text { to } 60 \\
\text { days }\end{array}$ \\
\hline \multicolumn{10}{|l|}{ Etiolation (E) } \\
\hline $\mathbf{E}_{0}$ & 29.24 & $4.37(33.61)$ & $5.37(38.98)$ & 8.07 & 8.47 & $6.03(14.50)$ & 1.90 & $2.90(4.80)$ & $1.10(5.90)$ \\
\hline $\mathbf{E}_{1}$ & 28.49 & $4.89(33.38)$ & $5.87(39.25)$ & 8.07 & 9.80 & $6.26(16.06)$ & 2.00 & $3.14(5.14)$ & $2.30(7.44)$ \\
\hline S.Em. \pm & 0.34 & 0.03 & 0.04 & 0.14 & 0.19 & 0.06 & 0.04 & 0.07 & 0.06 \\
\hline C.D. at $5 \%$ & NS & 0.09 & 0.13 & NS & 0.56 & 0.17 & NS & 0.22 & 0.18 \\
\hline \multicolumn{10}{|c|}{ Wrapping materials (W) } \\
\hline $\mathrm{W}_{1}$ & 29.01 & $4.77(33.78)$ & $5.74(39.52)$ & 8.17 & 9.50 & $6.41(15.91)$ & 1.90 & $3.17(5.07)$ & $2.61(7.68)$ \\
\hline $\mathrm{W}_{2}$ & 28.72 & $4.49(33.21)$ & $5.49(38.70)$ & 7.97 & 8.77 & $5.88(14.65)$ & 2.00 & $2.87(4.87)$ & $1.66(6.53)$ \\
\hline S.Em. \pm & 0.34 & 0.03 & 0.04 & 0.14 & 0.19 & 0.06 & 0.04 & 0.07 & 0.06 \\
\hline C.D. at 5\% & NS & 0.09 & 0.13 & NS & 0.56 & 0.17 & NS & 0.22 & 0.18 \\
\hline \multicolumn{10}{|l|}{ Rooting media (M) } \\
\hline $\mathbf{M}_{1}$ & 28.15 & $2.61(30.76)$ & $3.52(34.28)$ & 8.50 & 4.60 & $5.60(10.20)$ & 2.00 & $0.70(2.70)$ & $1.20(3.90)$ \\
\hline $\mathbf{M}_{2}$ & 29.40 & $6.02(35.42)$ & $6.85(42.27)$ & 7.90 & 13.60 & $6.70(20.40)$ & 1.90 & $3.70(5.60)$ & $2.90(8.50)$ \\
\hline $\mathbf{M}_{3}$ & 29.05 & $4.10(33.15)$ & $5.25(38.40)$ & 7.87 & 6.70 & $5.80(12.50)$ & 2.00 & $2.12(4.12)$ & $1.93(6.05)$ \\
\hline $\mathbf{M}_{4}$ & 29.14 & $4.99(34.13)$ & $6.04(40.17)$ & 7.89 & 10.30 & $6.00(16.30)$ & 2.00 & $2.31(4.31)$ & $2.12(6.43)$ \\
\hline $\mathrm{M}_{5}$ & 28.59 & $5.43(34.02)$ & $6.43(40.45)$ & 8.1 & 11.60 & $6.60(18.20)$ & 1.80 & $2.63(4.43)$ & $2.41(6.84)$ \\
\hline S.Em. \pm & 0.54 & 0.05 & 0.07 & 0.22 & 0.31 & 0.09 & 0.06 & 0.12 & 0.15 \\
\hline C.D. at $5 \%$ & NS & 0.15 & 0.21 & NS & 0.89 & 0.27 & NS & 0.34 & 0.43 \\
\hline C.V\% & 6.59 & 4.05 & 4.65 & 9.60 & 11.82 & 5.41 & 11.46 & 11.96 & 11.43 \\
\hline$(\mathbf{E} \times \mathbf{M})$ & NS & Sig. & NS & NS & NS & NS & NS & NS & NS \\
\hline$(\mathbf{W} \times \mathbf{M})$ & NS & $\mathrm{NS}$ & NS & NS & NS & $\mathrm{NS}$ & NS & $\mathrm{NS}$ & NS \\
\hline$(\mathbf{E} \times \mathbf{W})$ & NS & NS & NS & NS & NS & $\mathrm{NS}$ & NS & NS & NS \\
\hline$(\mathrm{E} \times \mathrm{W} \times \mathbf{M})$ & NS & NS & NS & NS & NS & NS & NS & NS & NS \\
\hline
\end{tabular}


Table.3 Interaction effect of etiolation and media on rooting and survival in air layering of guava (Psidium guajava L.) cv. Allahabad Safeda at detachment

\begin{tabular}{|c|c|c|c|c|c|c|c|c|}
\hline Treatment & 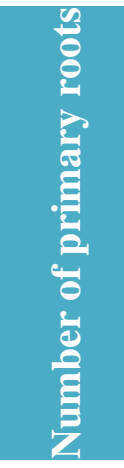 & 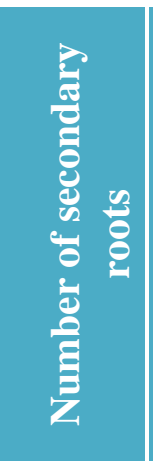 & 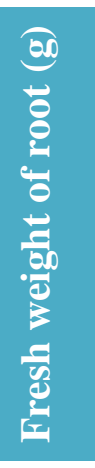 & 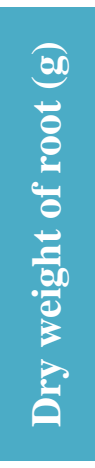 & 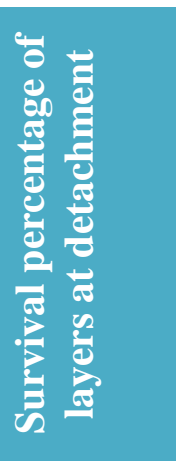 & 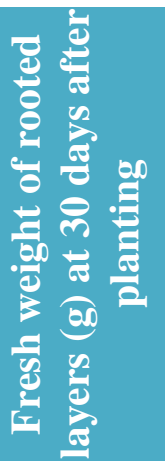 & 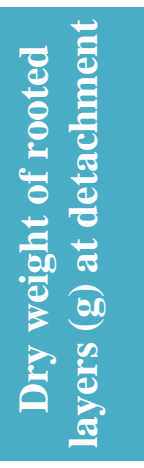 & 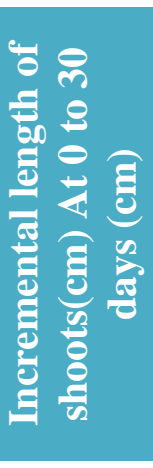 \\
\hline $\mathbf{E}_{0} \mathbf{M}_{1}$ & 2.83 & 8.50 & 1.01 & 0.18 & 49.52 & 13.86 & 5.15 & 2.31 \\
\hline $\mathbf{E}_{0} \mathbf{M}_{2}$ & 11.50 & 34.83 & 2.60 & 0.57 & 72.52 & 28.15 & 10.65 & 5.71 \\
\hline $\mathrm{E}_{0} \mathbf{M}_{3}$ & 4.50 & 13.33 & 1.41 & 0.32 & 56.06 & 17.65 & 6.38 & 3.73 \\
\hline $\mathbf{E}_{0} \mathbf{M}_{4}$ & 5.50 & 19.83 & 1.90 & 0.42 & 63.16 & 20.60 & 6.97 & 4.76 \\
\hline $\mathbf{E}_{0} \mathbf{M}_{5}$ & 7.83 & 25.16 & 2.27 & 0.49 & 67.73 & 25.63 & 8.91 & 5.35 \\
\hline $\mathrm{E}_{1} \mathbf{M}_{1}$ & 3.33 & 11.00 & 1.18 & 0.25 & 51.67 & 15.73 & 5.80 & 2.92 \\
\hline $\mathbf{E}_{1} \mathbf{M}_{2}$ & 12.66 & 40.33 & 2.96 & 0.72 & 77.97 & 30.81 & 11.65 & 6.32 \\
\hline $\mathbf{E}_{1} \mathbf{M}_{3}$ & 5.00 & 15.66 & 1.56 & 0.29 & 58.80 & 18.65 & 6.73 & 4.48 \\
\hline $\mathbf{E}_{1} \mathbf{M}_{4}$ & 7.83 & 22.50 & 2.15 & 0.43 & 65.47 & 23.66 & 8.01 & 5.21 \\
\hline $\mathbf{E}_{1} \mathbf{M}_{5}$ & 9.83 & 30.66 & 2.38 & 0.47 & 70.97 & 26.66 & 9.66 & 5.51 \\
\hline S.Em. \pm & 0.28 & 0.54 & 0.03 & 0.01 & 0.44 & 0.28 & 0.11 & 0.07 \\
\hline C.D. at $\mathbf{5 \%}$ & 0.81 & 1.55 & 0.11 & 0.03 & 1.27 & 0.81 & 0.31 & 0.21 \\
\hline C.V\% & 9.81 & 5.99 & 4.73 & 7.36 & 1.72 & 3.16 & 3.38 & 4.05 \\
\hline
\end{tabular}


While, at $30^{\text {th }}$ and $60^{\text {th }}$ days after planting $\left(\mathrm{E}_{1}\right)$ observed maximum Incremental length of shoots $(6.02 \mathrm{~cm}, 6.85 \mathrm{~cm})$, Incremental number of leaves $(13.60,6.70)$, Incremental number of branches $(3.70,2.90)$. Highest survival percentage of air layers might be due to better water holding capacity of sphagnum moss resulted in more number of primary and secondary roots, better length, number of leaves, etc. This combination have absorption of nutrients and moisture from the growing as well as created more favourable environment for good shoot growth resulting in higher survival percentage layering in guava. The results are quite comparable with results of Kadman and Slor (1974) who reported that the sphagnum moss as the best rooting medium for air layering in litchi. The results in respect to sphagnum moss are in conformity with finding of Rymbai and reddy (2010) in Guava air layering.

\section{Interaction effect of etiolation and rooting media}

Etiolation and rooting media had significant effect on rooting and shooting attributes and survival percentage (Table 3). Treatment combination $\left(\mathrm{E}_{1} \mathrm{M}_{2}\right)$ recorded maximum number of primary roots (12.66), secondary roots (40.33), fresh weight of root (2.96 g) and dry weight of root $(0.72 \mathrm{~g})$ at the time of detachment i.e. 45 days after layering. Whereas, maximum survival percent of rooted layers $(77.97 \%)$ at the time detachment, total fresh weight of layers (30.81) at 30 DAP, total dry weight of layers (11.65) at the time of detachment, Incremental length of $\operatorname{shoots}(\mathrm{cm})(6.32)$ at 0 to 30 days was noted in $E_{1} M_{2}$. The combination effect $\mathrm{E}_{1} \mathrm{M}_{2}$ was observed and enhanced rooting attributes and obtained highest survival percentage. This beneficial infraction effect of treatment might be due to favorable environment created by combination. Similar results were reported by
Rymbai and Reddy (2012). Furthermore Kadam and Slor (1974) reported that the sphagnum moss on best rooting and kunal and syamal (2005) reported positive effect of etiolation.

Based on the above result it was concluded that survival of rooted air layer at the time of detachment could be obtained in air layers with the treatment combination of etiolation and sphagnum moss. Beside it also improved root characters like number of primary and secondary roots, fresh and dry weight of roots.

\section{References}

Chadha, K. L. (2006). Handbook of Horticulture, Indian Council of Agriculture Research, New Delhi, 189194.

Kanpure, R. N., Barholia, A. K., Yadav, K. K., Singh, Lal and Gurjar, P. K. S. (2015). Effect of organic media, indole3 butyric acid and colour of polythene wrappers on success and survival of air layering of acid lime (Citrus aurantifolia Swingle). Bhartiya Krishi Anushandhan Patrika., 30 (2), 94-98.

Kunal, K. and Syamal, M. M. (2005). Effect of etiolation and plant growth substances in rooting and survival of air layers of guava (Psidium guajava L.). Indian Journal of Horticulture., 62 (3), 290-292.

Mishra, D. S., Thapa, K. S., Nimbolkar, P. K., Tripathi, A. and Singh, S. K. (2017). Efficacy of Different Rooting Media and Wrapping material on Air-Layers in Litchi (Litchi chinensis Sonn.) cv. 'Rose Scented'. International Journal of Chemical Studies, 5(6), 2004-2009.

Panse, V. G. and Shukhatme, P. V. (1978). 'Statistical Method for Agricultural Workers', 2nd Edition, Publ. by Indian 
Council of Agricultural Research, New Delhi.

Rymbai, H. and Reddy, G. S. (2010). Effect of IBA, time of layering and rooting media on air-layers and plantlets survival under different growing nursery conditions in guava. Indian $J$. Hort., 67, 99-104.

Rymbai, H., Reddy, G. S. and Reddy, K. C. S (2012). Effect of coco peat and sphagnum moss on guava (Psidium guajava L.) air layers and plantlets survival under open and poly house nursery. Agricultural Science Digest., 32 (3), 241-243.

Sengupta, S. and Thakur, S. (2001). Studies on the effect of growth regulators on rooting of air-layers of jack fruit (Artocarpus heterophyllus Lam.).
Orissa Journal Horticulture., 29 (1), 63-65.

Sengupta, S. and Thakur, S. (2001). Studies on the effect of growth regulators on rooting of air-layers of jack fruit (Artocarpus heterophyllus Lam.). Orissa Journal Horticulture, 29 (1), 6365.

Singh, D. K. and Bhuj, B. D. (2000). Response of air layering of guava (Psidium guajava L.) to paclobutrazol and coloured polywrappers. Agriculture Science Digest., 20 (3), 171-173.

Singh, M., Patel, Y. R. and Yadava, H. S. (1995). Success and survival of air layering as influenced by growth regulators and wrappers in guava (Psidium guajava L). Advance in plant Science., 8 (1), 183-188.

\section{How to cite this article:}

Chaudhari, H.J., B.H. Panchal, N.G. Patel and Sutariya, N.K. 2018. Effect of Etiolation, Wrapping Materials and Media on Rooting and Survival in Air Layering of Guava (Psidium guajava L.) cv. Allahabad Safeda. Int.J.Curr.Microbiol.App.Sci. 7(08): 382-389. doi: https://doi.org/10.20546/ijcmas.2018.708.043 